\title{
Climate Change, the Evaporation Paradox, and Their Effects on Streamflow in Lijiang Watershed
}

\author{
Long Jiao, Dongmei Wang* \\ College of Soil and Water Conservation, Beijing Forestry University, Beijing, China
}

Received: 29 October 2017

Accepted: 18 December 2017

\begin{abstract}
Global warming has become an indisputable fact over the past century, while much research has shown that the rate of potential evapotranspiration had been consistently decreasing throughout the world over the past 50 years. This phenomenon is called the "evaporation paradox." In this study we tested the trends of potential evapotranspiration and air temperature, and analyzed the effects of climate change on streamflow. The conclusions include:

1) The potential evapotranspiration of the Lijiang watershed is significantly decreased at the 0.1 confidence level and temperature is significantly increased at the 0.01 confidence level.

2) Evaporation paradox exists in the Lijiang watershed, caused mainly by sunshine duration decrease.

3) The annual streamflow and precipitation of Lijiang watershed both showed a decreased trend: compared between the first decade of 1976-1985 and the last decade of 2006-2015, streamflow decreased 8.48\% and precipitation decreased $7.65 \%$.

4) The sensitivities of streamflow to precipitation and potential evapotranspiration were 1.4152 and -0.4152 , respectively, and the effects of precipitation and potential evapotranspiration on streamflow were a $10.83 \%$ decrease and $1.67 \%$ increase, respectively.
\end{abstract}

Keywords: evaporation paradox, climate change, streamflow, sensitivity, Lijiang watershed

\section{Introduction}

Evaporation is a key link in the processes of global water cycle and energy cycle [1]. Terrestrial evapotranspiration contributes to $2 / 3$ of annual precipitation, or the equivalent amount of twice of total surface runoff [2-3]. Potential evapotranspiration is the theoretical limit and the calculation basis of actual evapotranspiration, and is widely used in water resource research [4]. At the same

*e-mail: bjfu_wangdm@126.com time, evapotranspiration plays an important role in the global energy budget [5]. Therefore, changes of potential evapotranspiration have a great impact on global hydrological and energy cycle [6].

Global warming has become an indisputable fact over the past century. According to the IPCC $5^{\text {th }}$ report, the surface temperature of the earth increased $0.85^{\circ} \mathrm{C}$ over 1880-2012 [7]. And it could be expected that global warming tends to result in an increase in evaporation, and this increase would cause water cycle intensified [8-9]. However, much research had shown that the rate of potential evapotranspiration had been consistently 
decreasing throughout the world over the past 50 years [10]. The contrast between temperature increase and potential evapotranspiration decrease is called the "evaporation paradox" [11].

This phenomenon was first reported by Peterson et al. (1995) [12], who tested the pan evaporation of America and the former Soviet Union in 1950-1990, and found a decreasing trend. Now the evaporation paradox has been a hot issue in evaporation study, similar trends have been found to be widely present in many regions and countries [13-17]. Under the background of global warming, what caused the decrease in potential evapotranspiration? Many researchers have suggested that, under the condition of not considering other factors, temperature increase must cause potential evapotranspiration increase, but the fact proves that the other factors played bigger contrary roles [18].

Precipitation and potential evapotranspiration are the most important meteorological variables influencing the changes of streamflow, and the partitioning of precipitation into streamflow and evaporation can be regarded as the key issue for understanding the response of hydrological processes to climate change at the basin scale [19]. Different methods were used to quantitatively separate the impacts of climatic variation on streamflow.
Among these methods, the climate elasticity method [20-21] was widely used in different regions of the world [22-25]. The climate elasticity method considers precipitation and potential evapotranspiration as the representative indicators to estimate the impacts of climatic variation on streamflow.

In this study, based on the daily meteorological data of the Lijiang watershed, we compare and analyze the variation of potential evapotranspiration, temperature, and precipitation, and try to explore whether there is the phenomenon of evaporation paradox in the Lijiang watershed. The sensitivities of precipitation and potential evapotranspiration on streamflow are also identified by the climate elasticity method. The purpose of this study was to investigate the evaporation paradox in the Lijiang watershed, and to further understand the effects of climate change on streamflow.

\section{Materials and Methods}

\section{Study Area}

Lijiang watershed is located in northeastern Guangxi, bounded by $24^{\circ} 38^{\prime}-25^{\circ} 54^{\prime} \mathrm{N}$ and $110^{\circ} 7^{\prime} \mathrm{E}-110^{\circ} 43^{\prime} \mathrm{E}$. The

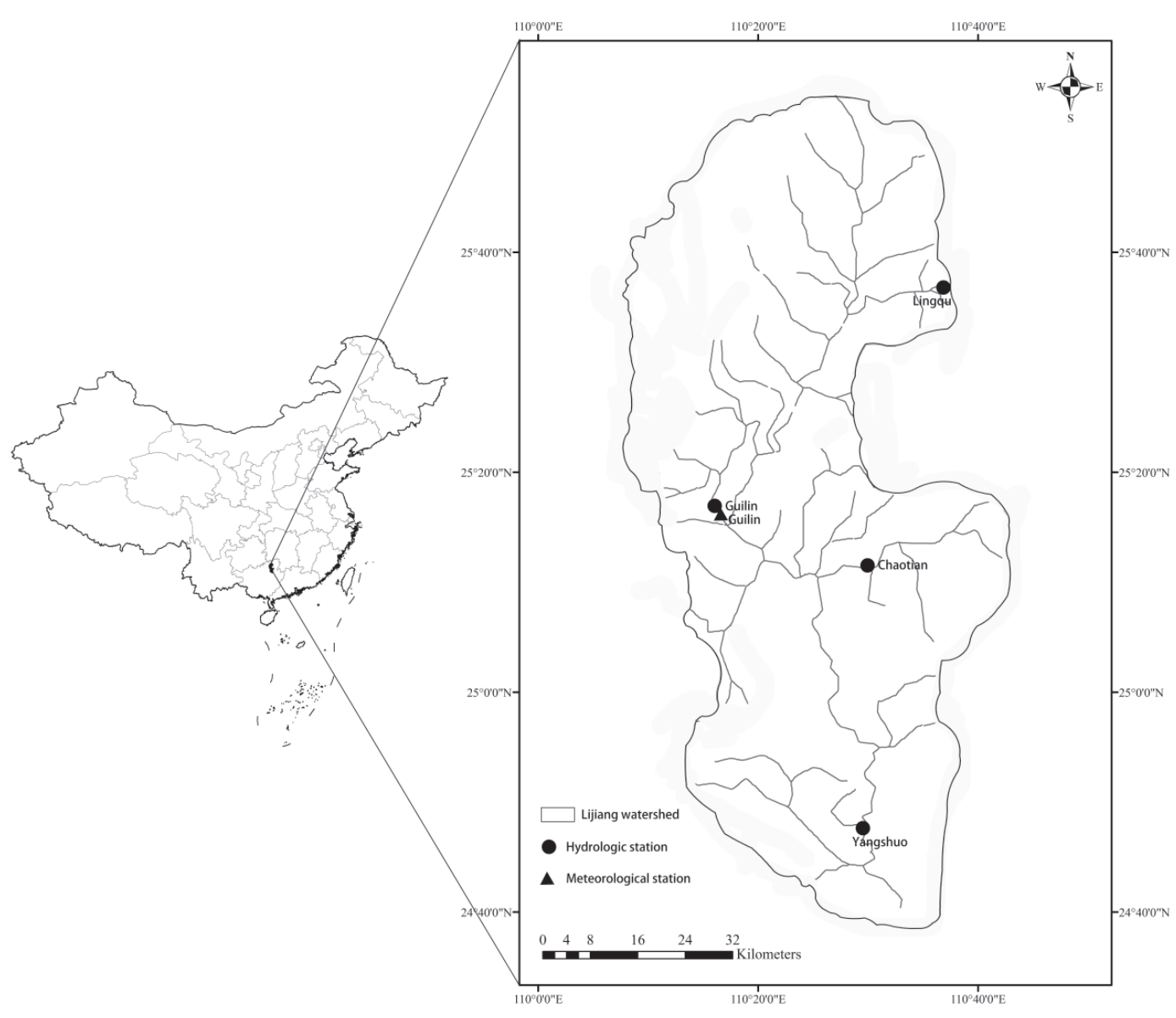

Fig. 1. Location of the study area. 
region has a total area of $5,306 \mathrm{~km}^{2}$. The topography is characterized by low mountains and hilly landscapes, and is higher in the north (elevation 900-1,100 m) and lower in the south (elevation 100-600 m). This region has a subtropical humid monsoon climate. The annual temperature is about $17 \sim 20^{\circ} \mathrm{C}$, annual precipitation is about $1,400 \sim 2,600 \mathrm{~mm}$, and annual evaporation is about $1,350 \sim 1,850 \mathrm{~mm}$, raining and hot during the same period. Vegetation is subtropical typical evergreen broad-leaved forest, like Pinus massoniana, Phyllostachys pubescens, and so on.

\section{Data}

The streamflow data were obtained from the Hydrological Yearbook of the People's Republic of China, mainly from 4 hydrological stations: Lingqu, Guilin, Chaotian and Yangshuo. Meteorological data were obtained from the China Meteorological Data Sharing Service System (www.cma.gov.cn), and involved daily precipitation, average temperature, maximum temperature, minimum temperature, relative humidity, wind speed, and sunshine duration. The location of all hydrological and meteorological stations can be seen in Fig. 1.

\section{Methods}

\section{Potential Evapotranspiration Calculation}

And the potential evapotranspiration data are calculated based on the FAO model [26], derived from the process-based Penman-Monteith ET equation assuming a hypothetical well-watered grass that has a $0.12 \mathrm{~m}$ canopy height, a leaf area of $4.8 \mathrm{~m}^{2} / \mathrm{m}^{2}$, a bulk surface resistance of $70 \mathrm{~s} / \mathrm{m}$, and an albedo of 0.23 . Briefly:

$$
\begin{gathered}
E_{p}=\frac{0.408 \Delta\left(R_{n}-G\right)+\gamma \frac{C}{T+273} \mu_{2}\left(e_{s}-e_{a}\right)}{\Delta+\gamma\left(1+0.34 \mu_{2}\right)} \\
\Delta=2503 \frac{e^{\frac{17.27 T}{T+273.3}}}{(T+237.3)^{2}}
\end{gathered}
$$

... where:

$\mathrm{Ep}=$ daily potential evapotranspiration $(\mathrm{mm})$

$\Delta=$ slope of the saturation water vapor pressure versus air temperature $\mathrm{T}\left(\mathrm{kPa}^{\circ} \mathrm{C}^{-1}\right)$

$\mathrm{Rn}=$ total net radiation $\left(\mathrm{MJ} / \mathrm{m}^{2}\right)$

$\mathrm{G}=$ total soil heat flux $\left(\mathrm{MJ} / \mathrm{m}^{2}\right.$, assumed zero in this study)

$\gamma=$ psychrometric constant $\left(\mathrm{kPa} .{ }^{\circ} \mathrm{C}^{-1}\right)$

$\mathrm{e}_{\mathrm{s}}=$ saturation vapor pressure $(\mathrm{kPa})$

$\mathrm{e}_{\mathrm{a}}=$ actual vapor pressure $(\mathrm{kPa})$

$\mu_{2}=$ mean wind speed at $2 \mathrm{~m}$ height $(\mathrm{m} / \mathrm{s})$

$\mathrm{C}=$ unit conversion factor with a value of 900

\section{Mann-Kendall Test}

Mann-Kendall test is one of the most widely used non-parametric tests to detect significant trends of climatic variables in time series [27-28]. The presence of a statistically significant trend is evaluated using the $Z$ value. The test statistic $\mathrm{Z}$ is as follows:

$$
Z=\left\{\begin{array}{clc}
\frac{S-1}{\sqrt{\operatorname{Var}(S)},} & \text { if } & S>0 \\
0 & \text { if } & S=0 \\
\frac{S+1}{\sqrt{\operatorname{Var}(S)},} & \text { if } & S<0
\end{array}\right.
$$

statistic S:

$$
\begin{gathered}
S=\sum_{i=1}^{n-1} \sum_{j=i+1}^{n} \operatorname{sgn}\left(x_{j}-x_{i}\right) \\
\operatorname{sgn}(x)=\left\{\begin{array}{lll}
1, & \text { if } & x_{j}-x_{i}>0 \\
0, & \text { if } & x_{j}-x_{i}=0 \\
-1, & \text { if } & x_{j}-x_{i}<0
\end{array}\right.
\end{gathered}
$$

...where $x_{i}$ and $x_{j}$ are 2 generic sequential data values of the variable, and $n$ is the length of the data set.

The statistic $S(\operatorname{Var}(S))$ can be calculated as:

$$
\operatorname{Var}(S)=\frac{n(n-1)(2 n+5)}{18}
$$

\section{Sensitivity Analysis Method}

The sensitivity coefficient (E) represents the proportional change in streamflow (Q) divided by the proportional change in a climatic variable $(\mathrm{X})$, such as precipitation or potential evapotranspiration [29], and is expressed as:

$$
\varepsilon=\frac{\partial Q / Q}{\partial X / X}
$$

The sensitivity coefficient of streamflow to precipitation $\left(\varepsilon_{p}\right)$ can be derived [30] as:

$$
\varepsilon_{P}=\frac{P}{Q}-\frac{(P-Q) E_{p}}{Q\left(E_{p}+P\right)}
$$

An analogue coefficient for the sensitivity to $E_{p}$ can be easily derived by combining both coefficients [31]:

$$
\varepsilon_{P}+\varepsilon_{E_{p}}=1
$$






Fig. 2. Long-term variations of potential evapotranspiration and air temperature.

\section{Results and Discussion}

\section{Climate Change}

\section{The Change Trends of Climate}

Temperature and potential evapotranspiration are the most obvious indicators to reflect climatic characteristics. The mean annual potential evapotranspiration was calculated by the method of Penman Monteith Equation for the national weather station within the study watershed from long-term (1976-2015) meteorological data.

Trend analysis is useful for understanding dynamics and behaviors of hydrological and climatic variables over a long-term period. The Mann-Kendall test was applied to detect the change trend of climate over the study period 1976 to 2015. Annual potential evapotranspiration in Lijiang watershed presents a decreasing trend from 1976 to 2015. Based on the Mann-Kendall test results, the Z statistic of Ep was -1.34. And that suggested, over the whole study period from 1976 through 2015, that the annual potential evapotranspiration showed a downward trend at the 0.1 confidence level. The long-term variation of air temperature showed an obvious increasing trend, no matter the daily average temperature, daily maximum temperature, or daily minimum temperature. Their $\mathrm{Z}$ statistics of Mann-Kendall test were 4.81, 3.39, and 5.11, respectively. And that means the air temperature increased over the period from 1976 to 2015, and was at the 0.01 confidence level.

\section{Evaporation Paradox in Lijiang Watershed}

The long-term variations of potential evapotranspiration $\left(\mathrm{E}_{\mathrm{p}}\right)$ and temperature $(\mathrm{T})$ of the Lijiang watershed are shown in Fig. 2. And the mean annual $\mathrm{E}_{\mathrm{p}}$ was $937.14 \mathrm{~mm}$.

Over the past 40 years from 1976 to 2015, a climate warming trend was obvious in Lijiang watershed. Annual average of daily mean air temperature was increasing at a rate of $0.323^{\circ} \mathrm{C}$ per decade. Over the same period, potential evapotranspiration appeared as a decreasing trend. Annual potential evapotranspiration was decreasing at a rate of $6.537 \mathrm{~mm}$ per decade. Therefore, we conclude that the evaporation paradox does exist in our study area of Lijiang watershed.

The evaporation paradox had been observed in many regions around the world. Although many researchers have tried to figure out its mechanism, we still do not have a unified understanding about it. What caused the decrease in potential evapotranspiration? Some possible reasons have been discussed by Peterson et al. (1995) and Roderick et al. (2002), who thought the reason was the sunlight decrease due to the increase in cloud coverage [11-12]. Stanhill et al. (2001) also thought the reason was the sunlight decrease while due to the increase in aerosol concentration [32]. Chattopadhyay et al. (1997) wrote that it was attributable to vapor pressure deficit decrease, which is due to increasing air humidity [33]. And Cohen et al. (2002) thought that it was attributable to wind speed decrease, which was due to the monsoon change [34]. Decreasing in solar radiation or sunlight, referred to as global dimming, could be the primary cause, but this trend changed to the reverse direction in the 1980s [35-36].

Table 1. The correlation between Ep and other weather factors.

\begin{tabular}{|c|c|c|c|c|c|c|c|c|}
\hline Correlation & $\mathrm{E}_{\mathrm{p}}$ & $\mathrm{P}_{\mathrm{a}}$ & $\mathrm{T}$ & $\mathrm{T}_{\max }$ & $\mathrm{T}_{\min }$ & $\mathrm{RH}$ & $\mathrm{W}$ & $\mathrm{S}$ \\
\hline $\mathrm{E}_{\mathrm{p}}$ & 1 & & & & & & & \\
\hline $\mathrm{P}_{\mathrm{a}}$ & 0.204 & 1 & & & & & & \\
\hline $\mathrm{T}$ & -0.097 & $-0.345^{*}$ & 1 & & & & \\
\hline $\mathrm{T}_{\max }$ & 0.078 & -0.185 & $0.928^{* *}$ & 1 & & & & \\
\hline $\mathrm{T}_{\min }$ & -0.265 & -0.345 & $0.926^{* *}$ & $0.762^{* *}$ & 1 & & & \\
\hline $\mathrm{RH}$ & -0.163 & 0.139 & $-0.542^{*}$ & $-0.548^{*}$ & $-0.438^{*}$ & 1 & & \\
\hline $\mathrm{W}$ & 0.248 & 0.255 & $-0.528^{*}$ & $-0.423^{*}$ & $-0.584^{*}$ & $0.313^{*}$ & 1 & \\
\hline $\mathrm{S}$ & $0.769^{* *}$ & $0.358^{*}$ & 0.094 & $0.347^{*}$ & -0.124 & $-0.359^{*}$ & 0.06 & 1 \\
\hline
\end{tabular}

${ }^{* *}$ Correlation is significant at the 0.01 level

${ }^{*}$ Correlation is significant at the 0.1 level 


\section{Relations between Potential Evapotranspiration and Other Weather Factors}

A correlation analysis was conducted between potential evapotranspiration $\left(\mathrm{E}_{\mathrm{p}}\right)$ and other weather factors such as atmospheric pressure $\left(\mathrm{P}_{\mathrm{a}}\right)$, mean daily air temperature $(T)$, max daily air temperature $\left(T_{\text {max }}\right)$, min daily air temperature $\left(\mathrm{T}_{\min }\right)$, relative humidity $(\mathrm{RH})$, wind $(\mathrm{W})$, and sunshine duration (S). Correlation coefficients based on records in different periods are shown in Table 1, and the bivariate correlation statistics was used to analyze the significance for potential evapotranspiration of independent variables.

As shown in Table 1, we got a positive correlation between potential evapotranspiration and sunshine duration, which is reasonable as radiation is an energy source for evaporation. Results showed that the correlation coefficient was 0.769 and was significant at the 0.01 level. Based on the Mann-Kendall test results, the Z statistic was -0.8738 . And that suggested, over the whole study period from 1976 through 2015, that the sunshine duration showed a downward trend.

And for other weather factors, the Mann-Kendall test results of relative humidity and wind speed showed that the $\mathrm{Z}$ statistics were -3.9031 and -4.8352 , respectively. That means the relative humidity and wind speed in Lijiang watershed were significantly decreased. While they were not so related to potential evapotranspiration, the correlation coefficients were -0.163 and 0.248 , and the coefficients of other factors were also very small. So in this study watershed, the evaporation paradox phenomenon may be caused by sunshine duration decrease.

In this study, we described the phenomenon of evaporation paradox in the Lijiang watershed, and the relationships between potential evapotranspiration and other weather factors showed that it had a positive correlation with sunshine duration, while other factors were not so related to it. And the results showed that in our study watershed the evaporation paradox phenomenon may be caused by sunshine duration decrease, and were similar to a previous study. Sunshine duration is one of the most important meteorological factors, and researchers have found that many regions in china had a decreasing trend in 1961-2000 - similar to the trend in other regions of the earth [37-38]. And in Guangxi Province (the location of the study area), sunshine duration also showed a decreasing trend of $-35.1 \mathrm{~h} / 10 \mathrm{a}[39]$.

\section{Effects of Climate Change on Streamflow}

\section{The Changes of Streamflow and Precipitation}

Based on our study period of 1976-2015, we test the annual streamflow in the first decade of 1976-1985 and the last decade of 2006-2015. And the comparison results showed that the streamflow of Lijiang watershed had a decreasing trend (Fig. 3). The mean annual

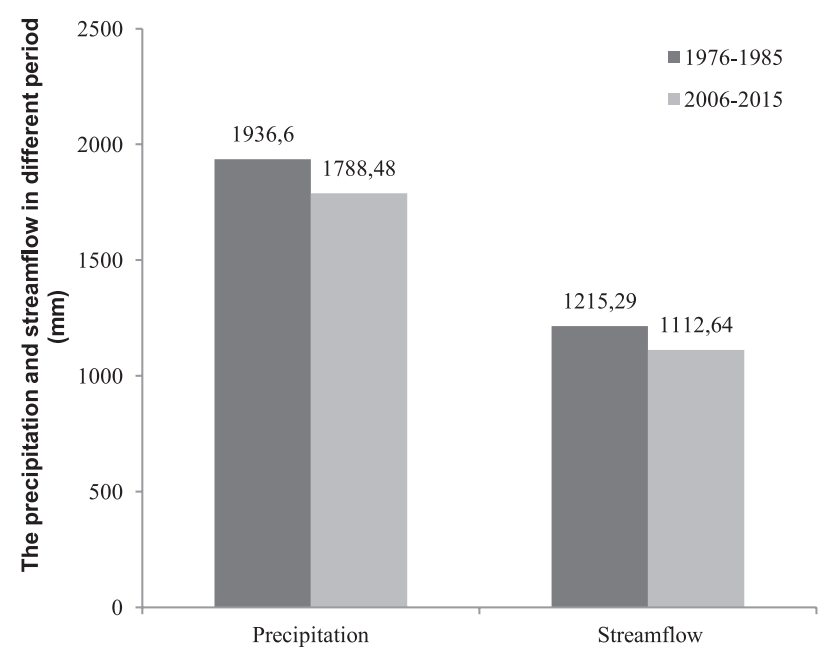

Fig. 3. Comparison of precipitation and streamflow in different periods.

streamflow in 1976-1985 was $1,215.29 \mathrm{~mm}$ and the streamflow in 2006-2015 was $1,112.64$ - a decrease of $8.48 \%$.

Precipitation is the most important factor to affect streamflow. The mean annual streamflow in the period of 1976-2015 was $1,919.45 \mathrm{~mm}$, and the results of Mann-Kendall test showed that the $\mathrm{Z}$ statistic of precipitation was -0.5476 , meaning that the precipitation of Lijiang watershed had a decreasing trend. Comparing precipitation in the first decade of 1976-1985 and the last decade of 2006-2015, the mean annual streamflow in 2006-2015 was $1,788.48 \mathrm{~mm}$ and in $1976-1985$ was $1,936.60 \mathrm{~mm}$ - showing a decrease of $7.65 \%$.

\section{The Sensitivities and Effects of Climate Change on Streamflow}

The sensitivity of streamflow to precipitation was determined by Eq. 8, and the value was 1.4152 . This result indicated that a $10 \%$ decrease in precipitation would result in a $14.152 \%$ decrease in streamflow. Similarly, the sensitivity value of streamflow to potential evapotranspiration was -0.4152 , and indicated that a $10 \%$ decrease in potential evapotranspiration would result in a $4.152 \%$ increase in streamflow.

Based on a comparison of the first decade of 1976-1985 and the last decade of 2006-2015, precipitation showed a decrease of $7.65 \%$, and for the sensitivity value of streamflow to precipitation was 1.4152 , we calculated that the precipitation affected streamflow in a $10.83 \%$ decrease. Likewise, comparing 1976-1985 and 2006-2015, the potential evapotranspiration showed a decrease of $4.02 \%$, and for the sensitivity value of streamflow to potential evapotranspiration of 0.4152 , the effect of potential evapotranspiration on streamflow was an increase of $1.67 \%$.

Many previous studies have shown that precipitation (reflecting the available water) is the key variable influencing hydrological processes, while the effects 
of potential evapotranspiration (reflecting the energy conditions) were smaller, and we got a similar conclusion in our study. In Lijiang watershed, the sensitivity coefficients of precipitation and potential evapotranspiration on streamflow are 1.4152 and -0.4152 , respectively. This means that streamflow is more sensitive for precipitation than potential evapotranspiration, and based on these results, the effect of precipitation on streamflow is $10.83 \%$ - much larger than potential evapotranspiration of a $1.67 \%$ increase.

It is important to highlight that there remains some uncertainty in this statistical assessment of climate impacts on streamflow. In our study, we used the approach of Renner et al. (2012) [30] to estimate the sensitivity of streamflow to climate. A problem is that this approach is more suitable for applying to an area where precipitation and potential evapotranspiration are of similar magnitude [30], in other words, aridity is close to one, while in our study area precipitation is much larger than potential evapotranspiration, meaning that the aridity index is smaller than one. That may lead to some error in our results, and we would make some modification in future research

\section{Conclusions}

Changes in climate and their effects on streamflow are important parts of the hydrological cycle and a complicated feedback to climate change exists. A better understanding of the impacts of climate change on streamflow is becoming increasingly important for water resource management and planning. In this study, we test the change trend of climate, and quantify the sensitivity of streamflow to climate. The findings can be summarized as follows:

1) The climate of the Lijiang watershed has a significant change trend. The Mann-Kendall test results showed that potential evapotranspiration is significantly decreased at the 0.1 confidence level and temperature is significantly increased at the 0.01 confidence level.

2) An evaporation paradox exists in Lijiang watershed while the climate becomes warmer and potential evapotranspiration keeps decreasing. This phenomenon may be mainly caused by a sunshine duration decrease.

3) The annual streamflow and precipitation of Lijiang watershed both showed a decreasing trend. Comparing the first decade of 1976-1985 and the last decade of 2006-2015, streamflow decreased $8.48 \%$ and precipitation decreased $7.65 \%$.

4) The sensitivities of streamflow to precipitation and potential evapotranspiration were 1.4152 and -0.4152 , respectively. And the effects of precipitation and potential evapotranspiration on streamflow were a $10.83 \%$ decrease and $1.67 \%$ increase, respectively.

\section{Acknowledgements}

This research was supported by the National Scientific and Technological Plans (2012BAC16B03).

\section{Reference}

1. YANG K., YE B., ZHOU D., WU B., FOKEN T. Response of hydrological cycle to recent climate changes in the Tibetan Plateau. Climatic Change. 109, 517, 2011.

2. REDDY V.R., SYME G.J. Social sciences and hydrology: An introduction. Journal of Hydrology. 518, 1, 2014.

3. WANG X.S., ZHOU Y. Shift of annual water balance in the Budyko space for a catchment with groundwater dependent evapotranspiration. Hydrology \& Earth System Sciences Discussions. 20, 3673, 2015.

4. PENG B., LIU X., YANG T., LI F., LIANG K., HU S., LIU C. Assessment of the influences of different potential evapotranspiration inputs on the performance of monthly hydrological models under different climatic conditions. Journal of Hydrometeorology. 2259, 17, 2016.

5. XIE J., SUN G., CHU H., LIU J., MCNULTY S., NOORMETS A., JOHN R., OUYANG Z., ZHA T., LI H., GUAN W., CHEN J. Long-term variability in the water budget and its controls in an oak-dominated temperate forest. Hydrological Processes. 6054, 28, 2015.

6. LIU C., ZHANG D. Temporal and spatial change analysis of the sensitivity of potential evapotranspiration to meteorological influencing factors in China. Acta Geographica Sinica. 66, 579, 2011.

7. IPCC. Climate Change 2013. Working group I contribution to the IPCC fifth assessment report, 2013. The Physical Science Basis: Summary for Policymakers.

8. ABTEW W., OBEYSEKERA J., IRICANIN N. Pan evaporation and potential evapotranspiration trends in South Florida. Hydrological Processes. 25, 958, 2015.

9. FICKLIN D.L., MAXWELL J.T., LETSINGER S.L., GHOLIZADEH H. A climatic deconstruction of recent drought trends in the United States. Environmental Research Letters. 10, 1, 2015.

10. STOCKER F., QIN D., PLATTNER G.K., TIGNOR M., ALLEN S., BOSHUNG A., NAUELS A., XIA Y., BEX V., MIDGLEY P. IPCC, 2013: Climate Change 2013: The Physical Science Basis. Contribution of Working Group I to the Fifth Assessment Report of the Intergovernmental Panel on Climate Change. Computational Geometry. 18, 95, 2013.

11. XING W., WANG W., SHAO Q., YU Z., YANG T., FU J. Periodic fluctuation of reference evapotranspiration during the past five decades: Does Evaporation Paradox really exist in China?. Scientific Reports. 6, 39503, 2016.

12. PETERSON T.C., GOLUBEV V.S., GROISMAN P.Y. Evaporation losing its strength. Nature. 377, 687, 1995.

13. WANG T., ZHANG J., SUN F., LIU W. Pan evaporation paradox and evaporative demand from the past to the future over China: a review. Wiley Interdisciplinary Reviews Water. 2017.

14. LU X., BAI H., MU X. Explaining the evaporation paradox in Jiangxi Province of China: Spatial distribution and temporal trends in potential evapotranspiration of Jiangxi Province from 1961 to 2013. International Soil \& Water Conservation Research. 4, 45, 2016. 
15. BURN D.H., HESCH N.M. Trends in evaporation for the Canadian Prairies. Journal of Hydrology. 336, 61, 2007.

16. JHAJHARIA D., DINPASHOH Y., KAHYA E., SINGH V.P., FAKHERI-FARD A. Trends in reference evapotranspiration in the humid region of northeast India. Hydrological Processes. 26, 421, 2012.

17. ZHANG Q., QI T., LI J., SINGH V.P., WANG Z. Spatiotemporal variations of pan evaporation in China during 1960-2005: changing patterns and causes. International Journal of Climatology. 35, 903, 2015.

18. MCVICAR T.R., RODERICK M.L., DONOHUE R.J., NIEL T.G.V. Less bluster ahead? Ecohydrological implications of global trends of terrestrial near-surface wind speeds. Ecohydrology. 5, 381, 2012.

19. LIU X., LIU W., XIA J. Comparison of the streamflow sensitivity to aridity index between the Danjiangkou Reservoir basin and Miyun Reservoir basin, China. Theoretical \& Applied Climatology. 111, 683, 2013.

20. BABEL M.S., BHUSAL S.P., WAHID S.M., AGARWAL A. Climate change and water resources in the Bagmati River Basin, Nepal. Theoretical \& Applied Climatology. 115, 639, 2014

21. WANG L., LIU H.L., BAO A.M., PAN X.L., CHEN X. Estimating the sensitivity of runoff to climate change in an alpine-valley watershed of Xinjiang, China. Hydrological Sciences Journal. 61, 1069, 2015

22. ANDREASSIAN V., CORON L., LERAT J., MOINE N.L. Climate elasticity of streamflow revisited - an elasticity index based on long-term hydrometeorological records. Hydrology \& Earth System Sciences Discussions. 12, 3645, 2016.

23. LI B., CHEN F. Using the aridity index to assess recent climate change: a case study of the Lancang River Basin, China. Stochastic Environmental Research \& Risk Assessment. 29, 1071, 2015.

24. FAN H., XU L., TAO H., FENG W., CHENG J., YOU H. Accessing the Difference in the Climate Elasticity of Runoff across the Poyang Lake Basin, China. Water. 9, 135, 2017.

25. LIU X., LIU C., LUO Y., XIA J. Dramatic decrease in streamflow from the headwater source in the central route of China's water diversion project: Climatic variation or human influence? Journal of Geophysical Research Atmospheres. 117, 6113, 2012.

26. ALLEN R.G., PEREIRA L.S., RAES D., SIMITH M. Crop evapotranspiration: Guidelines for computing crop water requirements. FAO Irrigation and Drainage Paper 56. Rome, Italy: United Nations FAO. 1998.

27. HAMED K.H. Trend detection in hydrologic data: the Mann-Kendall trend test under the scaling hypothesis. Journal of Hydrology. 349, 350, 2008.
28. LIANG L.Q., LI L.J., LIU Q.A. Temporal variation of reference evapotranspiration during 1961-2005 in the Taoer River basin of Northeast China. Agricultural \& Forest Meteorology. 150, 298, 2010.

29. HU S., LIU C., ZHENG H., WANG Z., YU J. Assessing the impacts of climate variability and human activities on streamflow in the water' source area of Baiyangdian Lake. Journal of Geographical Sciences. 22, 895, 2012.

30. RENNER M., SEPPELT R., BERNHOFER C. Evaluation of water-energy balance frameworks to predict the sensitivity of streamflow to climate change. Hydrology \& Earth System Sciences \& Discussions. 213, 98, 2012.

31. PEEL M.C., MCMAHON T.A., FINLAYSON B.L. Vegetation impact on mean annual evapotranspiration at a global catchment scale. Water Resources Research. 46, 2095, 2010.

32. STANHILL G., COHEN S. Global dimming: a review of the evidence for a widespread and significant reduction in global radiation with discussion of its probable causes and possible agricultural consequences. Agricultural \& Forest Meteorology. 107, 255, 2001.

33. ABTEW W., OBEYSEKERA J., IRICANIN N. Pan evaporation and potential evapotranspiration trends in South Florida. Hydrological Processes. 25, 958, 2015.

34. STANHILL G., MOLLER M. Evaporative climate change in the British Isles. International Journal of Climatology. 28, 1127, 2010.

35. HOSSAIN S., HOMMA K., SHIRAIWA T. Decadal and monthly change of an empirical coefficient in the relation between solar radiation and the daily range of temperature in Japan: implications for the estimation of solar radiation based on temperature.[J]. Plant Production Science. 17, 333, 2014.

36. WANG J., DONG J., WANG S., LU G., Oyler J., SMITH W.K., ZHAO M., LIU J., RUNNING S. Decreasing net primary production due to drought and slight decreases in solar radiation in China from 2000 to 2012. Journal of Geophysical Research. 122, 261, 2017.

37. WANG Y., WILD M., SANCHEZ-LORENZO A., MANARA V. Urbanization effect on trends in sunshine duration in China. Annales Geophysicae. 35, 839, 2017.

38. SHEN X., LIU B., LI G., WU Z., JIN Y., YU P., ZHOU D. Spatiotemporal change of diurnal temperature range and its relationship with sunshine duration and precipitation in China. Journal of Geophysical Research Atmospheres. 119, 13, 2015.

39. YE Y., SU Y.X., LI Z., WANG Y., LIANG J. The analysis on sunshine duration spatial and temporal variations over Guangxi in recent 50 years. Chinese Agricultural Science Bulletin. 29, 196, 2013 [In Chinese]. 
